\title{
The effect of quantum teaching on students' motivation on social studies (An quasi experiment for 5th grade elementary school)
}

\author{
Khairunnisa ${ }^{1}$, Yalvema Miaz ${ }^{2}$, Yeni Karneli ${ }^{3}$ \\ ${ }^{123}$ Universitas Negeri Padang, Padang - Indonesia, (nisa66387@gmail.com)
}

\begin{abstract}
This research was concerned by students' low motivation on social studies. This research aims to determine the difference of the students' learning motivation taught using Quantum Teaching and conventional teaching model on social studies. This research applied quasi-experiment with nonequivalent control group design. The samples were taken with simple random sampling technique, with samples as many as 44 students. Analysis of data used t-test. The result showed that the students' motivation with Quantum Teaching were higher than conventional teaching model on social studies, where by using statistical test, the tvalue was 5,624 and table was 2,089 or knowable tvalue> table. It can be concluded that Quantum Teaching model has positive effect to improve students' learning motivation.
\end{abstract}

Keywords: quantum teaching, learning motivation, social studies.

\section{Introduction}

Elementary school is the level of education that becomes a place to put the knowledge, attitude, and basic skills that must be taken by students to be the basis to pursue secondary education. Social studies as a subject at the elementary school is essentially an integration of various social disciplines and other relevant disciplines to realize educational goals at the primary school level (Rahmaniah, 2012). Social studies is designed to develop students' knowledge and comprehension toward social conditions of society in entering a dynamic life of society (Mutiani, 2017). Social studies is very important for students in developing their knowledge, attitudes, and skills in order to take an active part in life later as a member of society and good citizens. Social studies can not be separated from various problems, which many students consider social studies as a boring and dislike subject. One of reason that cause students less like social studies is because social studies lesson taught has not been meaningful for students. Many students have not been able to find a connection between social studies subjects with its usefulness in studentsreal-life (Chapin, 2014). Many teachers feel they need to struggle more to motivate students in learning, especially in social studies subject, where students consider that social studies is a boring lesson (Hung \& Fan, 2014).

Motivation is the overall driving force within the student to carry out a series of learning activities to achieve the predetermined learning objectives (Palupi, Anitah, \& Budiyono, 2014). Students' motivation leads to learning activities, which ensures the continuity of the learning activities and gives direction to the learning activities, so that the objectives desired by the learning subject can be achieved (Moos \& Honkomp, 2011). Motivation is a key factor in determining the quality of long-term 
learning (Navickienè, Kavaliauskien \&Pevcevičiūtè, 2015). Students with high motivation will be more serious, diligent, active in learning, have high responsibilities in carrying out learning activities, and always try to learn with best results (Bakar, 2014). Whereas students who have low motivation will lose the driving force and inspiration to act (Mattarima \& Hamdan, 2011). Students who have low learning motivation is indicated by a lack of diligence in doing tasks, easy to despair in learning, and attention is not directed to the lesson (Mokhoiyaroh \& Muzayyinah, 2014).

Based on the above theory, it can be concluded that the motivation to learn is an encouragement that is in the self that gives direction to the learning activities to achieve the learning objectives. The characteristics of motivation to learn are as follows: 1) diligent to face the task; 2) resilient in the face of adversity; 3) demonstrate interest in learning; 4) preferably working independently; 5) can maintain their opinion; and 6) pleased to solve problems (Sardiman, 2007, p. 83). Factors causing low learning motivation include dynamic elements in learning, teacher's efforts in teaching students, students' environmental conditions, students' conditions, students' abilities, and ideals of students (Santosa \& Us, 2016).

One of essential factor in improving students' learning motivation is by applying the appropriate learning model and in accordance with the characteristics of the students. In general, elementary school students are at a concrete operational stage in which the presentation of concepts and actions can only be obtained through real practice (Lee \& Chen, 2014). The fifth grades of elementary school have these characteristics of seeing the world operational and learning from the real thing. The use of innovative and fun learning models is needed in the social studies learning process because such learning models are able to make students more enthusiastic in learning activities.

Innovations in the world of education have created the development of varied learning models, one of which is the Quantum Teaching model. According to DePorter, Reardon, and Singer-Nourie (2014: 32-34) Quantum Teaching is a rousing learning alteration with all its nuances. Quantum Teaching rests on the concept of "bring their world to our world, and put our world into their world". This shows that in the learning activities students need to open the schemes to be then delivered into the subject matter. So that students can find the relation between the subject matter with their life and make the lesson more meaningful for the students.

Quantum Teaching has advantages, namely: 1 ) increase student motivation; 2 ) increase the value learning outcome; 3) increase confidence; 4) increase self-esteem, and 5) continue the use of skills (DePorter et al, 2014: 32). The use of Quantum Teaching model is chosen because by using the learning model can increase students' motivation. According to DePorter et al (2010, p.36-37) Quantum Teaching has five principles, namely: 1) everything speaks; 2) everything aims; 3) prior experience of naming; 4) recognize every effort; and 5) if worthy of study, then it is worth celebrating.

The learning step of Quantum Teaching is EELDRC, that is Enroll, Experience, Label, Demonstrate, Review, Celebrate (Acat \& Ay, 2014). In learning, this design can be used to inspire the spirit of learning, so they are interested in learning. For teachers, this design can be used to ensure that they experience learning, practice, make actual material for learners, and achieve success (Mulyasa, 2014, p. 89).

This is also supported by some previous research, among them Rohmanurmeta (2015) in his research shows that the use of Quantum Teaching model can improve students' learning motivation in science class IV learning. In addition, Indrawati, Indrasati, Supriadi (2016) found that the Quantum Teaching model with student worksheet based on cartoon physics had a significant effect on students' learning motivation in physics learning.

Based on the description, then with this experiment research to study the influence of Quantum Teaching Model on learning motivation in social studies lesson of grade V elementary school students with the hypothesis that students' learning motivation taught using Quantum Teaching model were 
higher than students' learning motivation taught using conventional learning model on learning social studies.The purpose of this research is to compare students' learning motivation who are taught using Quantum Teaching model who are taught using conventional learning model on social studies learning. In general, this research shows that students' learning motivation taught using Quantum Teaching model were higher than students' learning motivation taught using conventional learning model on learning social studies.

\section{Method}

This research is a quasi experimental research. The design used in this research is nonequivalent control group design, because it does not randomize the existing classes at the research site so that the comparable group takes from the existing classes (Wulandari, 2013). This research was conducted in the odd semester of the academic year 2017/2018. Population in this research is student of class V of SDN 002 Tembilahan. The samples in this research were 22 students in experimental class and 22 students in control class. Sampling in this research using simple random sampling technique, with VB as control class and VD as experiment class. This research involves independent variables and dependent variables. Independent variable in this research is Quantum Teaching model, while the dependent variable of this research is motivation. The instrument used to measure learning motivation is the questionnaire. The data in this research were analyzed by using t-test on N_gain of students' motivation data. Accounting N_gain for measure increas of students' motivation data. Prior to hypothesis testing, prerequisite data analysis is done by performing normality test using liliefors test and homogeneity test using $\mathrm{f}$ test, because before use $\mathrm{t}$ test, the data must be normal and homogeneous.

\section{Results and Discussion}

Motivation data obtained are then interpreted and analyzed. The percentage data of learning motivation are grouped using criteria that include: very high (80-100), high (66-79), moderate (56-65), low (40-55), and very low (<40) (Puspitasari, Setyosari, \& Amirudin, 2016). The results of data analysis of learning motivation are as follows:

Table.1 Learning motivation

\begin{tabular}{ccccc}
\hline Class & \multicolumn{2}{c}{ Pretest } & \multicolumn{2}{c}{ Posttest } \\
& Average Score & $\begin{array}{c}\text { Average } \\
\text { Percentage }\end{array}$ & Average Score & Average \\
& & 46.14 & 125.05 & Percentage \\
Experiment & 83.05 & 47.55 & 106.86 & 69.47 \\
Control & 85.59 & 59.37 \\
\hline
\end{tabular}

Based on table 1, it is found that the percentage of students' learning motivation in the experimental class before the learning using Quantum Teaching model is $46.14 \%$ with the low category and the students' learning motivation in the control class before the learning is $47.55 \%$ with the low category. After the learning activity using Quantum Teaching model in the experimental class the mean of student's learning motivation increased to $69.47 \%$ with high category and learning motivation in control class after learning activity was $59.37 \%$ with medium category.

The average acquisition of student learning motivation in the experimental class and control class is as follows. 
Table 2. N_gain of Learning Motivation in Experiment Class and Control Class

\begin{tabular}{ccc}
\hline Class & N_gain & Upgrading Criteria \\
Experiment & 0.44 & Medium \\
Control & 0.23 & Low \\
\hline
\end{tabular}

Based on table 2, the average of N_gain for the experimental class is 0.44 with moderate criteria. While the average N_gain for control class is 0.23 with low criterion. Although N_gain in the experimental class is classified as moderate, this data indicates that the improvement of students' learning motivation in the experimental class is greater than the improvement of motivation in the control class.

The data obtained are prerequisite test with normality test and homogeneity test. From the calculation, obtained results that data is normal and homogeneous so followed by uji-t. The $t$ test is performed on N_gain and posttest data. The t-test on N_gain is to show the difference in the increase of learning motivation of the experimental class students who were taught using the Quantum Teaching model than the control class taught using conventional learning.

Table 3. Hypothesis Test the Effect of Quantum Teaching on Learning Motivation

\begin{tabular}{ccccccccc}
\hline Data & Class & $\mathbf{N}$ & $\mathbf{S}$ & $\boldsymbol{\alpha}$ & $\mathbf{d f}$ & $\mathbf{t}_{\text {value }}$ & $\mathbf{t}$ table & Explanation \\
\hline N_gain & Experiment & 22 & 0.016 & 0.05 & 42 & 5.624 & 2.0189 & Accept $\mathrm{H}_{1}$ \\
& Control & 22 & & & & & & \\
\hline
\end{tabular}

The table 3 shows that the price of $t$ value is 5.624, whereas $t$ table is 2.0189. It can be concluded

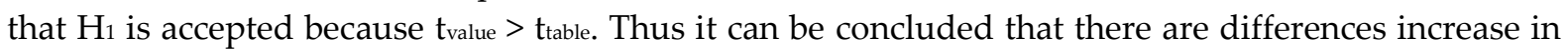
students' learning motivation after treatment in the experimental class and control class. The difference in increased learning motivation is caused by the treatment of different learning models. The Quantum Teaching model applied to the experimental class creates a more comfortable and enjoyable learning environment for students. In Quantum Teaching learning model there are steps that can improve students' learning motivation. The initial step of the Quantum Teaching model is to enroll. In this phase the teacher opens the students' schemata by entering the world of students and bringing them into learning activities. This will create relevance between the student world and the subject matter. Furthermore, students can easily interpret the benefit of lesson for them. If students know the benefits of course material then the students will be more motivated to learn it, because the material to be learned feels useful for life. When learning is related to real life, student learning motivation can increase (Cetin-Dindar, 2015).

In addition, in Quantum Teaching there are steps to celebrate. Conducting celebrations will encourage students to be more enthusiastic and responsible in learning activities. According to DePorter (2012: 63) the celebration done in the learning process will teach students about the essential motivation. Students will await exciting learning activities and build a desire for success. In addition to celebration, the recognition of the efforts of students in learning activities which is one of the principles of Quantum Teaching is also able to generate self-confidence and motivation to continue learning.

Quantum Teaching is a learning that makes the learning process that takes place becomes more fun and helps teachers in motivating students (Mulyasa, 2014). In order for the motivation to arise from the students themselves, the learning can be directed through fun activities (Triastuti, Akbar, \& Irawan, 2016). In conventional learning also begins by opening the students schemata about the material taught and conveyed the lesson objectives but did not emphasize the benefit of lesson and in the learning activities are dominated by dull question and answer activities for students. 
Nevertheless, the reinforcement of student learning activities remains to be given to students in the control class. These activities are still less able to improve students' learning motivation rapidly.

The results of this research are supported by previous research on Quantum Teaching model, such as Indrawati, et al (2016) which found that the model of Quantum Teaching with student's worksheet based on cartoon physics have a significant effect on students' learning motivation on Physics learning. Angrianti (2014) concluded that the application of Quantum Teaching model significantly influence on students' learning motivation in integrated social studies subjects.

\section{Conclusions}

Based on the result of research, it can be concluded that student's learning motivation who taught with Quantum Teaching were higher than conventional teaching model on social studies for fifth grade of elementary school students. It make implication on commitment to applied Quantum Teaching model in social studies for fifth grade students of elementary school.

\section{References}

Acat, M. B. \& Ay, Y. (2014). An investigation the effect of quantum learning approach on primary school 7th grade students' science achievement, retention and attitude. Educational Research Association The International Journal of Research in Teacher Education, 5(2), 11-23.

Angrianti, W, (2014).Pengaruh penerapan model pembelajaran quantum teaching terhadap motivasi belajar siswa mata pelajaran ips terpadu kelas VIII SMP Negeri 3 Tenggarong. Jurnal Pendidikan dan Pembelajaran, 2(2).

Bakar, R. (2014). The effect of learning motivation on student's productive competencies in vocational high school, West Sumatra. International Journal of Asian Social Science, 4(6), 722-732.

Cetin-Dindar, A. (2016). Student motivation in constructivist learning environment. Eurasia journal of mathematics, science \& technology education, 12(2), 233-247.

Chapin, J. R. (2006) Introduction: do elementary school students and their teachers really dislike social studies?. The Social Studies, 97(5), 187-188.

DePorter, B., Reardon, M., \& Singer-Nourie, S. (2010). Quantum Learning: Membiasakan Belajar Nyaman dan Menyenangkan. Terjemahan oleh Ary Nilandari. Bandung: Kaifa.

Hung, C., \& Fan, C. (2014). Perceived classroom management and student learning motivation in social studies of Taiwan Junior High School students. European Journal of Research in Social ciences, 2(3), 40-51.

Indrawati, Indrasati, H., \&, Supriadi, B. (2016). Pengaruh model quantum teaching disertai lks berbasis kartun fisika terhadap hasil dan motivasi belajar siswa dalam pembelajaran Fisika di SMA. Jurnal Pembelajaran Fisika, 5(1):30-34.

Lee, C \& Chen, M. (2014). Effects of worked examples using manipulatives on fifth graders' learning performance and attitude toward mathematics. Educational Technology \& Society, 18 (1), 264-275.

Mattarima, K., \& Hamdan, A. H. (2011). Learners' motivation and learning strategies in english foreign language (efi) in indonesian context. Journal of Edupres,1(1), 100-108.

Mokhoiyaroh \& Muzayyinah, M. (2014). Konseling behavior dalam mengatasi siswa dengan motivasi belajar rendah (studi kasus di SMA Negeri 1 Suboh - Situbondo). Jurnal Kependidikan Islam, 4(2), 281,308 .

Moos, D.C., \& Honkomp, B. (2011). Adventuring learnig: motivating student in a Minnesota Middle School. Journal of Research on Technology in Education, 43(3), 231-254.

Mulyasa, E. (2014). Guru dalam Implementasi Kurikulum 2013. Bandung: Remaja Rosdakarya Offset.

Mutiani. (2017). IPS dan pendidikan lingkungan: urgensi pengembangan sikap kesadaran lingkungan peserta didik. Sosio Didaktika: Social Science Education Journal, 4(1), 45-5. 
Navickienė, V., Kavaliauskien, D., \& Pevcevičiūtè, S. (2015). Aspects of ESP learning motivation in Tertiary Education. Tiltai, 2, 97-108.

Palupi, R., Anitah, S., \& Budiyono. (2014). Hubungan antara motivasi belajar dan persepsi siswa terhadap kinerja guru dalam mengelola kegiatan belajar dengan hasil belajar IPA siswa kelas VIII di SMPN 1 Pacitan. Jurnal Teknologi Pendidikan dan Pembelajaran, 2(2).

Puspitasari, E., Setyosari, P., \& Amirudin, A. (2016). Peningkatan motivasi dan hasil belajar melalui think pair share (tps) di sekolah dasar. Jurnal Pendidikan, 1(7):1432-1436.

Rahmaniah, A. (2012). Pengembangan pembelajaran ilmu pengetahuan sosial pada pendidikan dasar. Madrasah, 5(1), 94-112.

Rohmanurmeta, F. M. (2015). Peningkatan motivasi belajar IPA melalui metode pembelajaran quantum teaching bagi siswa kelas IV. Premiere Educandum, 5(2), 253- 262.

Santosa, D. T., \& Us, T. (2016). Faktor-faktor penyebab rendahnya motivasi belajar dan solusi penanganan pada siswa kelas XI jurusan teknik sepeda motor, Jurnal Pendidikan Teknik Otomotif, XIII(2).

Sardiman, A.M. (2012). Interaksi dan Motivasi Belajar Mengajar. Jakarta: Raja Grafindo Persada.

Triastuti, D., Akbar, S., \& Irawan, E. B. (2016). Penggunaan Media Papan Permainan Untuk Meningkatkan Motivasi Belajar Siswa di Sekolah Dasar. Makalah disajikan dalam seminar nasional pengembangan profesionalisme pendidik untuk membangun karakter anak bangsa. Universitas negeri Malang, 2.

Wulandari, B. (2013). Pengaruh Problem-Based Learning Terhadap Hasil Belajar Ditinjau Dari Motivasi Belajar PLC di SMK. Jurnal Pendidikan Vokasi, 3(2): 178-191. 